\title{
ПОКАЗНИКИ ПРООКСИДАНТНО-АНТИОКСИДАНТНОЇ СИСТЕМИ ПЕЧІНКИ ПРИ ЕКСПЕРИМЕНТАЛЬНОМУ АНТИФОСФОЛІПІДНОМУ СИНДРОМІ ТА ЗАСТОСУВАННI L-АРГІНІНУ
}

Вступ. Антисроссроліпідний синдром, в основі розвитку якого лежить автоімунний механізм, нерідко $\epsilon$ причиною невиношування вагітності, тромбозів судин різної локалізації, інсультів, серцево-судинних та інших захворювань, що супроводжуються істотною активацією вільнорадикальних процесів. Патогенез ураження печінки при антифроссроліпідному синдромі вивчено недостатньо.

Мета дослідження - встановити зміни показників прооксидантно-антиоксидантної системи і тканинного дихання в печінці при експериментальному антифоосфроліпідному синдромі та застосуванні L-apгініну.

Методи дослідження. Дослідження проводили на мишах лінії BALB/c. Антифросфроліпідний синдром моделювали за допомогою кардіоліпіну, який емульгували в 75 мкл повного ад'юванту Фрейнда, наступні ін'єкції проводили з неповним ад'ювантом Фрейнда. Кардіоліпін вводили внутрішньом'язово 4 рази (30 мкг на одну ін'єкцію, проміжки між ін'єкціями становили 14 діб). Для корекції використовували L-аргініну гідрохлорид (25 мг/кг) - один раз на день упродовж 10 діб після фрормування антифросфроліпідного синдрому. $B$ тканині печінки досліджували активність та вміст компонентів антиоксидантної системи (супероксиддисмутази, каталази, відновленого глутатіону). Рівень продуктів вільнорадикального окиснення ліпідів визначали за вмістом гідропероксидів ліпідів та ТБК-активних продуктів. Стан енергозабезпечувальних процесів мітохондрій досліджували за активністю сукцинатдегідрогенази та цитохромоксидази. Концентрацію білків визначали за методом Лоурі.

Результати й обговорення. При антифросфоліпідному синдромі в печінці відзначено порушення рівноваги у функціонуванні прооксидантно-антиоксидантної системи (підвищення активності супероксиддисмутази і каталази, зменшення вмісту відновленого глутатіону, зростання рівня гідропероксидів ліпідів, ТБК-активних продуктів), електронно-транспортного ланцюга мітохондрій (зниження активності сукцинатдегідрогенази, цитохромоксидази). На фроні введення L-аргініну при експериментальному антифоссроліпідному синдромі встановлено відновлення активності та вмісту компонентів антиоксидантної системи, ензимів електронно-транспортного ланцюга мітохондрій, зниження вмісту гідропероксидів ліпідів і ТБК-активних продуктів у печінці.

Висновок. За умов експериментального антифоосфоліпідного синдрому L-аргінін зменшує прояви оксидативного стресу та відновлює активність ензимів електронно-транспортного ланцюга мітохондрій у ткканині печінки мишей лінії BALB/c.

КЛЮЧОВІ СЛОВА: антифосфоліпідний синдром; печінка; оксидативний стрес; антиоксидантна система

ВСТУП. Антисроссроліпідний синдром (АФС) це автоімунне захворювання, яке характеризується рецидивними артеріальними або венозними тромбозами різної локалізації, невиношуванням вагітності, тромбоцитопенією, а також неврологічними, серцево-судинними та іншими порушеннями [1-3].

Антифоссроліпідний синдром поділяють на первинний і вторинний. При первинному АФС спостерігають синтез антифоссроліпідних антитіл

(с) О. 3. Яремчук, К. А. Посохова, А. Р. Брик, М. І. Куліцька, І. П. Кузьмак, Н. Я. Мехно, 2017.
(аФЛ). Вторинний АФС розвивається на фроні системних захворювань сполучної тканини, онкологічних і гематологічних захворювань, інорекцій, васкулітів, приймання деяких лікарських препаратів [4-6]. Катастрофрічний АФС може виникнути за умов як первинного, так і вторинного АФС, характеризується поширеним тромбозом, що призводить до поліорганної недостатності та смерті пацієнтів, незважаючи на проведену інтенсивну терапію. Провокуючими фракторами для його розвитку можуть стати хірургічні втручання (наприклад, гістеректомія, кесарів розтин, 
холецистектомія), в тому числі навіть невеликі (екстракція зуба, біопсія), відміна антикоагулянтів, використання деяких лікарських препаратів (найчастіше оральних контрацептивів), онкологічні захворювання [1, 6].

Діагностичними маркерами АФС $€$ антифросфроліпідні антитіла: 1) антитіла до кардіоліпіну (аКЛ); 2) вовчаковий антикоагулянт; 3) антитіла, які реагують із комплексом компонентів кардіоліпіну, фросфратидилсерину, фоосфатидилінозитолу, фросфатидної кислоти; 4) $\beta$-2-глікопротеїн-І-кофракторозалежні антитіла [1, 2, 7]. За сучасними уявленнями, аФЛ - це гетерогенна популяція автоантитіл, що реагують 3 негативно зарядженими, рідше нейтральними, фроссроліпідами та розпізнають широкий спектр антигенних детермінант фоссроліпідозв'язувальних антикоагулянтних білків ( $\beta$-2-глікопротеїн-І, анексин V, протромбін). Антифроссоліпідні антитіла - це не тільки серологічні маркери, а й важливі патогенетичні медіатори, що викликають розвиток основних клінічних проявів АФС [3, 8]. При взаємодії аФЛ із фросфоліпідами мембран тромбоцитів, клітин ендотелію судин, нейронів, міокардіоцитів, гепатоцитів розвивається дисбаланс компонентів коагуляційно-фрібринолітичних цитокінових і кінінових каскадів $[1,8]$.

Антифосфроліпідні антитіла виявляють у $21 \%$ осіб, які перенесли інфаркт міокарда, у 20-40 \% при ішемічному інсульті, в 5-15 \% жінок 3 невиношуванням вагітності, у третини пацієнтів із системним червоним вовчаком. Клінічні прояви розвиваються у 30-50 \% хворих з підвищеним вмістом аКЛ. У разі виявлення аФЛ при системному червоному вовчаку ризик розвитку тромбозів збільшується до 60-70 \% [4, 5, 9].

Відомо, що оксидативний стрес сприяє дисфункції імунокомпетентних клітин і синтезу автоантитіл та $є$ одним із важливих компонентів патогенезу АФС [10, 11]. Встановлено позитивні кореляційні зв'язки аКЛ з рівнем F2-ізопростанів, чутливі маркери пероксидного окиснення ліпідів (ПОЛ) in vivo, що свідчить про посилення оксидативного стресу при АФС $[11,12]$. Проте в основному дослідники аналізували роль оксидативного стресу, викликаного аКЛ при АФС, лише на рівні плазми. Водночас клітинні та молекулярні механізми розвитку і регуляції оксидативного стресу при цій патології залишаються невивченими [12-14].

У хворих з АФС виділяють такі фрорми патології печінки: синдром Бадда-Кіарі; обструкцію дрібних печінкових вен; вузлову регенераторну гіперплазію; інфаркт печінки (трапляється рідко, в основному у вагітних при HELLP-синдромі або в післяпологовий період); хронічний гепатит [1, $15,16]$.
Незважаючи на існування ряду наукових досліджень, присвячених вивченню значення оксидативного стресу в механізмах розвитку АФС $[8,11,13,17]$, його роль у патобіохімічних механізмах ураження печінки при цій патології залишається недостатньо з'ясованою.

Мета дослідження - встановити зміни показників прооксидантно-антиоксидантної системи і тканинного дихання в печінці при експериментальному антифоосороліпідному синдромі та застосуванні L-аргініну.

МЕТОДИ ДОСЛІДЖЕННЯ. Дослідження проводили на 30 мишах лінії BALB/c (самках), яких утримували на стандартному раціоні віварію. Експерименти виконували з дотриманням принципів біоетики відповідно до Загальних етичних принципів експериментів на тваринах, ухвалених на Першому національному конгресі з біоетики (Київ, 2000) й узгоджених з положеннями Європейської конвенції про захист хребетних тварин, що використовуються для дослідних та інших наукових цілей (Страсбург, 1986), і Директиви Європейського Союзу 2010/10/63 EU щодо експериментів на тваринах. Антифосфоліпідний синдром моделювали за допомогою кардіоліпіну (“Sigma”, США), який вводили внутрішньом'язово 4 рази (30 мкг на одну ін'єкцію, проміжки між ін'єкціями становили 14 діб) [18]. Для підвищення ефективності імунної відповіді його емульгували в 75 мкл повного ад'юванту Фрейнда (перша ін'єкція), наступні ін'єкції проводили з неповним ад'ювантом Фрейнда. Антифоссроліпідний синдром формувався через 2 тижні після останньої ін'єкції кардіоліпіну.

Піддослідних тварин поділили на 3 групи: 1-ша (контроль) - інтактні тварини; 2-га - тварини з експериментальним АФС; 3-тя - тварини 3 АФС, яким вводили L-аргініну гідрохлорид ("Sigma", США, 25 мг/кг). L-аргініну гідрохлорид вводили внутрішньочеревно один раз на день, повторно, впродовж 10 діб після фрормування АФС. Тварини контрольної групи отримували внутрішньочеревно ідентичні об'єми розчинника. По 10 мишей із кожної групи виводили з експерименту через 10 діб з моменту підтвердження АФС за умов тіопентал-натрієвого наркозу (внутрішньочеревне введення $1 \%$ розчину з розрахунку 50 мг/кг маси тварини). Для дослідження використовували 10 \% гомогенати печінки. Тканину печінки охолоджували в середовищі виділення, яке містило 0,25 М сахарози, 1 мМ ЕДТА та 10 мМ трис-HCl-буфрер (pH 7,4) [19].

Активність супероксиддисмутази (СОД, КФ 1.15.1.1) визначали за ступенем зниження відновлення нітротетразолію синього за присутності НАДН ${ }_{2}$ і френазинметасульфрату [20]. Активність 
каталази (КАТ, КФ 1.11.1.6) досліджували згідно 3 методом [21], фріксуючи зміну оптичної щільності в результаті реакції пероксиду водню з молібдатом амонію. Вміст відновленого глутатіону (G-SH) визначали за здатністю його вільних SH-груп взаємодіяти з 5,5'-дитіо-біс-2-нітробензойною кислотою з утворенням тіонітрофенільного аніона, кількість якого прямо пропорційна вмісту G-SH [22]. Рівень продуктів вільнорадикального окиснення ліпідів оцінювали за вмістом гідропероксидів ліпідів (ГПЛ) [23] (ґрунтується на здатності екстрагованих гептан-ізопропіловою сумішшю ГПЛ інтенсивно поглинати світло при довжині хвилі $\lambda=232$ нм) і ТБК-активних продуктів (ТБК-АП) [24] (визначали в реакції з 2-тіобарбітуровою кислотою). Стан енергозабезпечувальних процесів мітохондрій досліджували за активністю сукцинатдегідрогенази (СДГ, КФ 1.3.99.1) та цитохромоксидази (ЦХО, КФ 1.9.3.1). Мітохондрії виділяли методом диореренційного центрифугування гомогенату тканини печінки. Мітохондріальну фрракцію отримували, центрифугуючи без'ядерний супернатант протягом 10 хв при 6500 об./хв. Отриманий осад мітохондрій ресуспендували в середовищі виділення. Усі операції проводили на холоді. Активність СДГ визначали за відновленням ферриціаніду калію до ферроціаніду калію сукцинатом під дією СДГ [25]. Принцип методу визначення ЦХО ґрунтується на здатності останньої окиснювати диметил-пара-фенілендіамін і $\alpha$-насртол з утворенням індофенолового синього [26]. Концентрацію розчинних білків у гомогенаті вимірювали за методом Лоурі [27].

Статистичну обробку даних здійснювали за допомогою програми STATISTICA 10. Отримані величини порівнювали з використанням U-критерію Манна-Уїтні. Зміни вважали достовірними при $\mathrm{p} \leq 0,05$.

РЕЗУЛЬТАТИЙ ОБГОВОРЕННЯ. ВСТаНОВЛЕно, що у печінці тварин з АФС активувались вільнорадикальні процеси. Спостерігали збільшення вмісту ГПЛ на 52 \% відносно контролю (рис. 1). Первинні продукти пероксидного окиснення ліпідів (ГПЛ) не стійкі й швидко розкладаються 3 утворенням вторинних продуктів: альдегідів, кетонів, спиртів [19]. У результаті проведених досліджень встановлено збільшення вмісту ТБК-АП на $36 \%$ у печінці тварин з АФС відносно контролю (рис. 2). Основним компонентом ТБК-АП є малоновий діальдегід, який при взаємодії із $\mathrm{SH}$ - та $\mathrm{CH}_{3}$-групами білків пригнічує активність фрерментів, сприяє цитолізу, агрегації тромбоцитів і зменшенню синтезу простагландинів [19].

Відомо, що інтенсифрікація вільнорадикального окиснення поєднується з дискоординацією в системі прооксиданти - антиоксиданти [28]. Порушення балансу між концентрацією активних форм кисню (АФК) і компонентів антиоксидантної системи (АОC) призводить до оксидативного стресу, окисного пошкодження ДНК, білків та ліпідів [29]. Помірне зростання рівня АФК активує ферментативну ланку АОС. На початкових етапах оксидативного стресу збільшення супероксидного аніон-радикала може індукувати підвищення активності СОД [28]. У наших дослідженнях встановлено компенсаторне зростання в печінці активності СОД на 45 \% при АФС порівняно з показниками інтактних тварин (рис. 3). Отримані результати узгоджуються 3 даними інших дослідників [11]. Встановлено також збільшення активності КАТ на 26 \% відносно контролю (рис. 4). Одержані результати можна пояснити підвищенням активності СОД, яка каталізує реакцію перетворення супероксид-аніона до пероксиду водню - єдиного субстрату каталази.

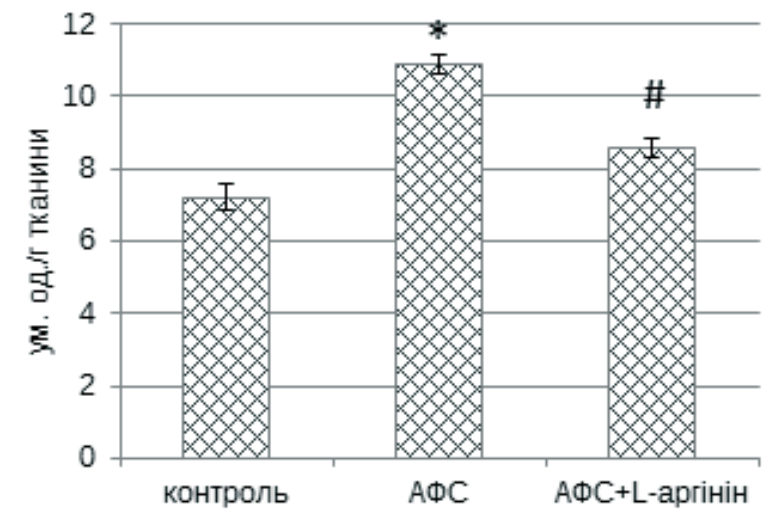

Рис. 1. Вміст гідропероксидів ліпідів у тканині печінки мишей лінії BALB/c за умов експериментального антифосороліпідного синдрому та при застосуванні L-аргініну (M $\pm \mathrm{m})$.

Примітка. Тут і на рисунках 2-5: * - різниця достовірна відносно контролю; \# - різниця достовірна відносно групи тварин з АФС $(p<0,05)$.

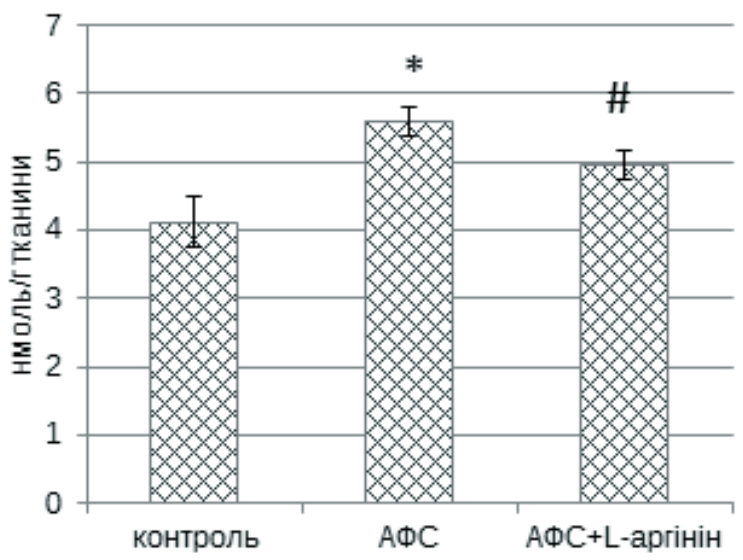

Рис. 2. Концентрація ТБК-активних продуктів у тканині печінки мишей лінії BALB/c за умов експериментального антифосфоліпідного синдрому та при застосуванні

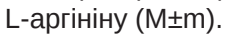




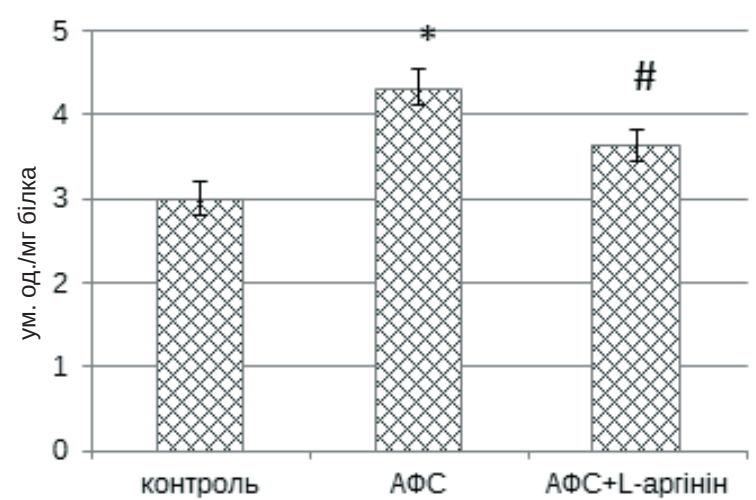

Рис. 3. Активність супероксиддисмутази у тканині печінки мишей лінії BALB/c за умов експериментального антифосфоліпідного синдрому та при застосуванні L-аргініну (M $\pm \mathrm{m})$.

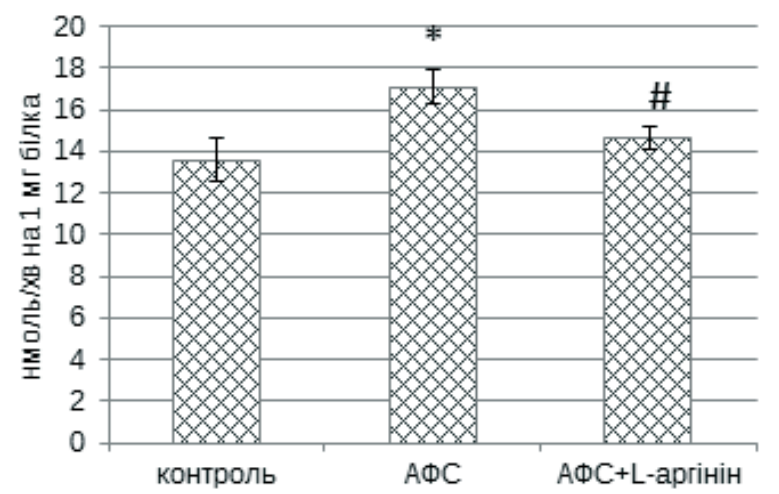

Рис. 4. Активність каталази у тканині печінки мишей лінії BALB/c за умов експериментального антифоссфоліпідного синдрому та при застосуванні L-аргініну (M $\pm m)$.

Утворений у мітохондріях і цитозолі пероксид водню розкладається глутатіонпероксидазою, а в пероксисомах - каталазою $[28,30]$. Функціональною основою системи антиоксидантного захисту є глутатіонова система, яка бере участь в інактивації пероксиду водню та ліпопероксидів, виконує захисну фрункцію для $\mathrm{SH}$-груп у протеїнах мембран [10]. У печінці мишей з АФС встановлено виснаження пулу G-SH, кількість якого зменшувалась на $21 \%$ порівняно з контрольною групою (рис. 5). За даними літератури [30], відновно-окиснювальний потенціал пари GSH/ GSSG наближається до термодинамічної рівноваги $з$ тіоловими групами протеїну і необхідний для збереження фуункціональної цілісності клітини. Зниження рівня G-SH в органах і тканинах призводить до оксидативного стресу [30].

Нагромадження продуктів ПОЛ спричиняє пошкодження генетичного апарату клітин, гальмує клітинний поділ, пригнічує окисне фоосфорилювання $[11,28]$. За результатами наших досліджень, у печінці тварин 2-ї групи порушувалось фрункціонування ензимів дихального ланцюга мітохондрій, про що свідчило зменшення активності СДГ і ЦХО відносно контролю.

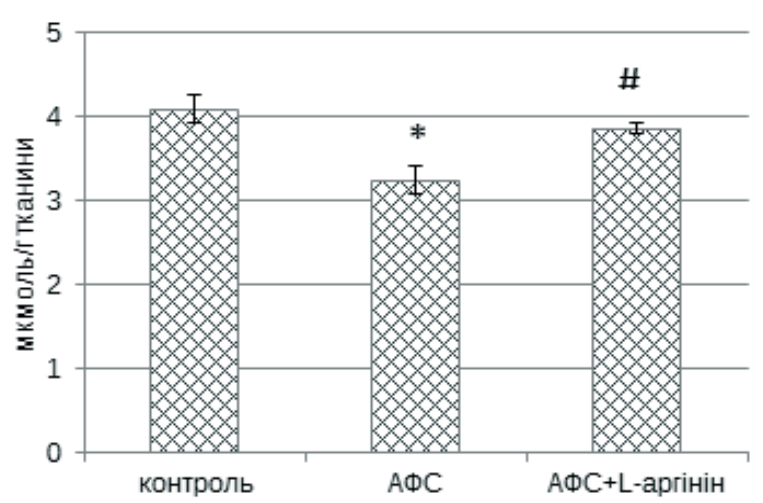

Рис. 5. Вміст відновленого глутатіону в тканині печінки мишей лінії BALB/c за умов експериментального антифросороліпідного синдрому та при застосуванні L-аргініну $(\mathrm{M} \pm \mathrm{m})$.

Встановлено, що на фроні введення L-аргініну пригнічувалась активність процесів переокиснення мембранних ліпідів у печінці: вміст ГПЛ зменшувався на $21 \%$, ТБК-АП - на $11 \%$ порівняно з показниками групи тварин з АФС (рис. 1, 2). Активність СОДу печінці знижувалась на $16 \%$, КАТ - на $14 \%$ порівняно $з$ показниками 2-ї групи (рис. 3, 4). У печінці мишей 3-ї групи вміст G-SH збільшувався на $19 \%$ порівняно 3 показниками групи тварин з АФС (рис. 5). Встановлено також зростання під впливом L-aргініну активності мітохондріальних ензимів у печінці (СДГ та ЦХО) відносно групи тварин з експериментальним АФС.

Отже, L-аргінін за умов експериментального антифоссроліпідного синдрому проявляє антиоксидантні й гепатопротекторні властивості, його дія спрямована на відновлення активності та вмісту компонентів АОС, ензимів електроннотранспортного ланцюга мітохондрій, зниження рівня ПОЛ у печінці.

ВИСНОВКИ. 1. За умов експериментального антифоссфоліпідного синдрому в тканині печінки мишей відбувається активація оксидативного стресу, порушення рівноваги в системі прооксиданти - антиоксиданти, що супроводжується накопиченням продуктів вільнорадикального окиснення, дискоординацією активності та вмісту компонентів системи антиоксидантного захисту й електронно-транспортного ланцюга мітохондрій.

2. Введення L-аргініну при антифроссроліпідному синдромі супроводжується зменшенням проявів оксидативного стресу, зокрема зниженням рівня пероксидного окиснення ліпідів у печінці, відновленням активності та вмісту компонентів антиоксидантної системи й ензимів мітохондріального електронно-транспортного ланцюга. 


\section{СПИСОК ЛІТЕРАТУРИ}

1. Насонов Е. Л. Антифоссфолипидный синдром / Е. Л. Насонов. - М. : Литтерра, 2004. - 440 с.

2. Якубовська І. О. Антисроссроліпідний синдром (синдром Х'юза) в лікарській практиці. Частина 1 / І. О. Якубовська, С. І. Геник // Клініч. імунологія. Алергологія. Інфектологія. - 2008. - № 4. - С. 31-36.

3. Горницкая О. В. Антифросфолипидный синдром / О. В. Горницкая // Експерим. та клініч. фрізіологія і біохімія. - 2008. - 4, № 1. - С. 61-70.

4. Alarcon-Segovia D. Long-term prognosis of antiphospholipid syndrome in patients with systemic lupus erythematosus / D. Alarcon-Segovia, A. Perez-Ruiz, A. R. Vila // J. Autoimmunity. - 2000. - 15. - P. 157-163.

5. Гуща О. В. Антисроссроліпідний синдром: історія, сучасність і перспективи / О. В. Гуща // Укр. журн. нефрології та діалізу. - 2006. - № 4. - С. 69-75.

6. щербакова М. Ю. Антифоссролипидный синдром у детей с соматической патологией / М. Ю. Щербакова, Т. М. Решетняк, Л. В. Жданова // Педиатрия. 2008. - 87, № 4. - С. 119-124.

7. Чернышов А. В. Современные вопросы патогенеза и диагностики антифоссролипидного синдрома (обзор литературы) / А. В. Чернышов, В.В.Талько, С. В. Андрейченко // Укр. мед. часоп. - 2013. - № 1. C. $122-125$.

8. Rand J. H. Molecular pathogenesis of the antiphospholipid syndrome / J. H. Rand // Circulation Research. 2002. - 90. - P. 29-37.

9. Oxidative protein damage and antioxidant status in systemic lupus erythematosus / Q. Zhang, D. Q. Ye G. P. Chen, Y. Zheng // Clin. Exp. Dermatol. - 2010. - 35, № 3. - P. 287-294.

10. Perricone C. Glutathione: a key player in autoimmunity / C. Perricone, C. De Carolis, R. Perricone // Autoimmun. Rev. - 2009. - 8, № 8. - P: 697-701.

11. Mitochondrial dysfunction in antiphospholipid syndrome: implications in the pathogenesis of the disease and effects of coenzyme Q10 treatment / C. PerezSanchez, P. Ruiz-Limon, M. Angeles Aguirre [et al.] // Blood. - 2012. - 119, № 24. - P. 5859-5870.

12. Enhanced lipid peroxidation in patients positive for antiphospholipid antibodies / L. Iuliano, D. Practico, D. Ferro [et al.] // Blood. - 1997. - 90, № 10. - P. 39313935.

13. Antiphospholipid antibodies are associated with enhanced oxidative stress, decreased plasma nitric oxide and paraoxonase activity in an experimental mouse model / J. D. Alves, L. J. Mason, P. R. J. Ames [et al.] // Rheumatology. - 2005. - 44. - P. 1238-1244.

14. High density lipoprotein inversely related to its specific autoantibody favouring oxidation in thrombotic primary antiphospholipid syndrome / P. R. Ames, E. Matsuura, J. R. Batuca [et al.] // Lupus. - 2010. - 19, № 6. P. $711-716$

15. Hepatic infarctions during pregnancy are associated with the antiphospholipid syndrome and in addition with complete or incomplete HELLP syndrome / R. Pauz- ner, M. Dulitzky, H. Carp [et al.] // Journal of Thrombosis and Haemostasis. - 2003. - 1. - P. 1758-1763.

16. Голубова О. А. Поражение печени при антифоосфолипидном синдроме / О. А. Голубова // Мистецтво лікування. - 2007. - № 3. - С. 35-41.

17. Alves J. D. Oxidative stress in systemic lupus erythematosus and antiphospholipid syndrome: a gateway to atherosclerosis. / J. D. Alves, B. Grima // Curr. Rheumatol. Rep. - 2003. - 5, № 5. - P. 383-390.

18. Морфологічний стан матки та плаценти при експериментальному моделюванні гестаційного антифоссроліпідного синдрому на мишах / Г.В.Зайченко, Ю. Б. Лар'яновська, Т. В. Деєва [та ін.] // Укр. мед. альм. - 2011. - 14, № 4. - С. 136-141.

19. Камышников В. С. Справочник по клинико-биохимическим исследованиям и лабораторной диагностике / В. С. Камышников. - М. : МЕДпресс-инфрорм, 2004. - 920 c.

20. Чевари С. Роль супероксиддисмутазы в окислительных процессах клетки и метод определения ее в биологических материалах / С. Чевари, И. Чаба, И. Секей // Лаб. дело. - 1985. - № 11. - С. 678-681.

21. Метод определения активности каталазы / М. А. Королюк, Л. И. Иванова, И. Г. Майорова [и др.] // Лаб. дело. - 1988. - № 1. - С. 16-19.

22. Ellman G. L. Tissue sulfhydryl groups / G. L. Ellman // Arch. Biochem. Biophys. - 1959. - 82. - P. 70-77.

23. Гаврилов В. Б. Спектрофротометрическое определение содержания гидроперекисей липидов в плазме крови / В. Б. Гаврилов, М. И. Мишкорудная // Лаб. дело. - 1983. - № 3. - С. 33-35.

24. Андреева Л. И. Модифрикация метода определения перекисей липидов в тесте с тиобарбитуровой кислотой / Л. И. Андреева, Л. А. Кожемякин, А. А. Кишкун // Лаб. дело. - 1988. - № 11. - С. 41-43.

25. Ещенко Н. Д. Определение количества янтарной кислоты и активности сукцинатдегидрогеназы / Н. Д. Ещенко, Г. Г. Вольский // Методы биохимических исследований. - Л. : Изд-во Ленинград. ун-та, 1982. С. $207-210$.

26. Кривченкова Р. С. Определение активности цитохромоксидазы в суспензии митохондрий / Р. С. Кривченкова // Современные методы в биохимии / под ред. В. Н. Ореховича. - М. : Медицина, 1977. - С. 47-49.

27. Protein measurement with the Folin phenol reagent / O. M. Lowry, N. J. Rosebrough, A. L. Farr, R. J. Randall // J. Biol. Chem.- 1951. - 193, № 1. - P. 265-275.

28. Активні фоорми кисню та їх роль у метаболізмі клітин / М. І. Колісник, Г.В.Колісник, Є. Нідзюлка, В. В. Влізло // Біологія тварин. - 2009. - 11, № 1-2. C. $59-70$.

29. Oxidative stress and fatigue in systemic lupus erythematosus / B. M. Segal, W. Thomas, X. Zhu [et al.] // Lupus. - 2012. - 21. - P. 984-992.

30. Мещишен I. Ф. Глутатіонова система організму за умов норми та патології / I. Ф. Мещишен. - Чернівці : Медакадемія, 1999. - 26 с. 


\section{REFERENCES}

1. Nasonov, E.L. (2004). Antifosfolipidnyy sindrom [Antiphospholipid syndrome]. Moscow: Litterra [in Russian].

2. Iakubovska, I.O., \& Henyk, S.I. (2008). Antyfosfolipidnyi syndrom (syndrom Khiuza) v likarskii praktytsi. Chastyna 1 [Antiphospholipid syndrome (Hughes syndrome) in medical practice. Part 1]. Klinichna imunolohiia. Alerholohiia. Infektolohiia - Clinical immunology. Allergology. Infectology, 4, 31-36 [in Ukrainian].

3. Gornitskaya, O.V. (2008). Antifosfolipidnyy sindrom [Antiphospholipid syndrome]. Eksperimentalna ta klinichna fiziolohiia ta biokhimiia - Experimental and Clinical Physiology and Biochemistry, 1 (4), 61-70 [in Russian].

4. Alarcon-Segovia, D., Perez-Ruiz, A., \& Vila A.R. (2000). Long-term prognosis of antiphospholipid syndrome in patients with systemic lupus erythematosus. J. Autoimmunity, 15, 157-163.

5. Hushcha, O.V. (2006). Antyfosfolipidnyi syndrom: istoriia, suchasnist i perspektyvy [Antiphospholipid syndrome: history, present and future]. Ukr. zhurnal nefrolohii ta dializu - Ukrainian Journal of Nephrology and Dialysis, 4, 69-75 [in Ukrainian].

6. Shcherbakova, M.Yu., Reshetnyak, T.M., \& Zhdanova L.V. (2008). Antifosfolipidnyy syndrom u detey s somaticheskoy patologiyey [Antiphospholipid syndrome in children with somatic pathology]. Pediatriya - Pediatrics, 87 (4), 119-124 [in Russian].

7. Chernyshov, A.V., Talko, V.V., \&Andreychenko S.V. (2013). Sovremennye voprosy patogeneza i diagnostiki antifosfolipidnogo sindroma: (obzor literatury) [Modern issues of pathogenesis and diagnosis of antiphospholipid syndrome: (review)]. Ukr. med. Chasopis - Ukrainian Medical Journal, 1, 122-125 [in Russian].

8. Rand, J.H. (2002). Molecular pathogenesis of the antiphospholipid syndrome. Circulation Research, 90, 29-37.

9. Zhang, Q., Ye, D.Q., Chen, G.P., \& Zheng, Y. (2010). Oxidative protein damage and antioxidant status in systemic lupus erythematosus. Clin. Exp. Dermatol., 35 (3), 287-294.

10. Perricone, C., Carolis, C.De, \& Perricone, R. (2009). Glutathione: a key player in autoimmunity. Autoimmun. Rev., 8 (8), 697-701.

11. Perez-Sanchez, C., Ruiz-Limon, P., \& Aguirre, M.A. (2012). Mitochondrial dysfunction in antiphospholipid syndrome: implications in the pathogenesis of the disease and effects of coenzyme Q10 treatment. Blood, 119 (24), 5859-5870.

12. Iuliano, L., Practico, D., \& Ferro D. (1997). Enhanced lipid peroxidation in patients positive for antiphospholipid antibodies. Blood, 90 (10), 3931-3935.

13. Alves, J.D., Mason, L.J., \& Ames P.R.J. (2005). Antiphospholipid antibodies are associated with enhanced oxidative stress, decreased plasma nitric oxide and paraoxonase activity in an experimental mouse model. Rheumatology, 44, 1238-1244.

14. Ames, P.R., Matsuura, E., \& Batuca J.R. (2010). High density lipoprotein inversely related to its specific autoantibody favouring oxidation in thrombotic primary antiphospholipid syndrome. Lupus, 19 (6), 711-716.

15. Pauzner, R., Dulitzky, M., Carp, H., Mayan, H., Kenett, R., Farfel, Z., \& Many A. (2003). Hepatic infarctions during pregnancy are associated with the antiphos- pholipid syndrome and in addition with complete or incomplete HELLP syndrome. Journal of Thrombosis and Haemostasis, 1, 1758-1763.

16. Golubova, O. A. (2007). Porazhenie pecheni pri antifosfolipidnom sindrome [Defeat of the liver under antiphospholipid syndrome]. Mystetstvo likuvannia - The Art of Treatment, 3, 35-41 [in Russian].

17. Alves, J.D., \& Grima, B. (2003). Oxidative stress in systemic lupus erythematosus and antiphospholipid syndrome: a gateway to atherosclerosis. Curr. Rheumatol. Rep., 5 (5), 383-390.

18. Zaichenko, H.V., Larianovska, lu.B., \& Deieva, T.V. (2011). Morfolohichnyi stan matky ta platsenty pry eksperymentalnomu modeliuvanni hestatsiinoho antyfosfolipidnoho syndromu na myshakh [Morphological state of the uterus and placenta in experimental modeling of gestational antiphospholipid syndrome in mice]. Ukrainskyi medychnyi almanakh - Ukrainian Medical Journal, 14 (4), 136-141 [in Ukrainian].

19. Kamyshnikov V.S. (2004). Spravochnik po klinikobiokhimicheskim issledovaniyam i laboratornoy diagnostike [Manual on Clinical Biochemical Research and Laboratory Diagnostics]. Moscow: MEDpress-inform [in Russian].

20. Chevari, S., Chaba, I., \& Sekey, I. (1985). Rol superoksiddismutazy $v$ okislitelnykh protsessakh kletki i metod opredeleniya ee $v$ biologicheskikh materialakh [The role of superoxide dismutase in the oxidative processes of the cell and the method for its determination in biological materials]. Lab. delo - Laboratory Work, 11, 678-681 [in Russian].

21. Korolyuk, M.A., Ivanova, L.I., \& Mayorova, I.G. (1988). Metod opredeleniya aktivnosti katalazy [Method for determining the activity of catalase]. Lab. delo Laboratory Work, 1, 16-19 [in Russian].

22. Ellman, G.L. (1959). Tissue sulfhydryl groups. Arch. Biochem. Biophys., 82, 70-77.

23. Gavrilov, V.B., \& Mishkorudnaya, M.I. (1983). Spektrofotometricheskoe opredelenie soderzhaniya gidroperekisey lipidov v plazme krovi [Spectrophotometric determination of the content of lipids hydroperoxides in blood plasma]. Lab. delo - Laboratory Work, 3, 33-35 [in Russian].

24. Andreyeva, L.I., Kozhemyakin, L.A., \& Kishkun, A.A. (1988). Modifikatsiya metoda opredeleniya perekisey lipidov $v$ teste s tiobarbiturovoy kislotoy [Modification of the method for determining lipid peroxides in a test with thiobarbituric acid]. Lab. delo - Laboratory Work, 11, 41-43 [in Russian].

25. Eshchenko, N.D., \& Volskiy G.G. (1982). Opredelenie kolichestva yantarnoy kisloty i aktivnosti suktsinatdegidrogenazy [Determination of amber acid and succinate dehydrogenase activity]. Metody biokhimicheskikh issledovaniy - Methods of Biochemical Research. Leningrad: Izd-vo Leningradskogo universiteta [in Russian].

26. Krivchenkova, R.S. (1977). Opredelenie aktivnosti tsitokhromoksidazy $v$ suspenzii mitokhondrii [Determination of the activity of cytochrome oxidase in suspension of mitochondria]. Orekhovich, V.N. (Ed.). Sovremennye metody $v$ biokhimii - Modern Methods in Biochemistry. Moscow: Meditsina [in Russian].

27. Lowry, O.M., Rosebrough, N.J., Farr, A.L., \& Randall, R.J. (1951). Protein measurement with the Folin phenol reagent. J. Biol. Chem., 193 (1), 265-275. 
28. Kolisnyk, M.I., Kolisnyk, H.V., \& Nidzyulka, Ye.E. (2009). Aktyvni formy kysniu ta yikh rol u metabolizmi klityn [Active forms of oxygen and their role in cell metabolism]. Biolohiia tvaryn - Biology of Animals, 1-2, 59-70 [in Ukrainian].

29. Segal, B.M., Thomas, W., Zhu, X., Diebes, A., McElvain, G., Baechler, E., \& Gross, M. (2012). Oxidative stress and fatigue in systemic lupus erythematosus. Lupus, 21, 984-992.

30. Meshchyshen, I.F. (1999). Hlutationova systema orhanizmu za umov normy ta patolohii [Glutathione system of the organism in conditions of normal and pathology]. Chernivtsi: Medakademiia [in Ukrainian].

О. 3. Яремчук, Е. А. Посохова, А. Р. Брик, М. И. Кулицкая, И. П. Кузьмак, Н. Я. Мехно ТЕРНОПОЛЬСКИЙ ГОСУДАРСТВЕННЫЙ МЕДИЦИНСКИЙ УНИВЕРСИТЕТ ИМЕНИ И. Я. ГОРБАЧЕВСКОГО

\section{ПОКАЗАТЕЛИ ПРООКСИДАНТНО-АНТИОКСИДАНТНОЙ СИСТЕМЫ ПЕЧЕНИ ПРИ ЭКСПЕРИМЕНТАЛЬНОМ АНТИФОСФОЛИПИДНОМ СИНДРОМЕ И ПРИМЕНЕНИИ L-АРГИНИНА}

\section{Резюме}

Вступление. Антифросфролипидный синдром, в основе развития которого лежит аутоиммунный механизм, нередко является причиной невынашивания беременности, тромбозов сосудов различной локализации, инсультов, сердечно-сосудистых и других заболеваний, которые сопровождаются существенной активацией свободнорадикальных процессов. Патогенез поражения печени при антифосфролипидном синдроме изучен недостаточно.

Цель исследования - установить изменения показателей прооксидантно-антиоксидантной системы и тканевого дыхания в печени при экспериментальном антиоросоролипидном синдроме и применении L-аргинина.

Методы исследования. Исследования проводили на мышах линии BALB/c. Антифросфролипидный синдром моделировали с помощью кардиолипина, который эмульгировали в 75 мкл полного адъюванта Фрейнда, последующие инъекции проводили с неполным адъювантом Фрейнда. Кардиолипин вводили внутримышечно 4 раза (30 мкг на одну инъекцию, промежутки между инъекциями составляли 14 суток). Для коррекции использовали L-аргинина гидрохлорид (25 мг/кг) - один раз в день на протяжении 10 суток после фрормирования антифосфолипидного синдрома. В ткани печени исследовали активность и содержание компонентов антиоксидантной системы (супероксиддисмутазы, каталазы, восстановленного глутатиона). Уровень продуктов свободнорадикального окисления липидов определяли по содержанию гидропероксидов липидов и ТБК-активных продуктов. Состояние энергообеспечивающих процессов митохондрий исследовали по активности сукцинатдегидрогеназы и цитохромоксидазы. Концентрацию белков определяли по методу Лоури.

Результаты и обсуждение. При антифосоролипидном синдроме в печени отмечено нарушение равновесия в фрункционировании прооксидантно-антиоксидантной системы (повышение активности супероксиддисмутазы и каталазы, уменьшение содержания восстановленного глутатиона, возрастание уровня гидропероксидов липидов, ТБК-активныхпродуктов), электронно-транспортной цепи митохондрий (снижение активности сукцинатдегидрогеназы, цитохромоксидазы). На фроне введения L-аргинина при экспериментальном антифоссролипидном синдроме установлено восстановление активности и содержания компонентов антиоксидантной системы, энзимов электронно-транспортной цепи митохондрий, снижение содержания гидропероксидов липидов и ТБК-активных продуктов в печени.

Вывод. В условиях экспериментального антифоссролипидного синдрома L-аргинин уменьшает проявления оксидативного стресса и восстанавливает активность энзимов электронно-транспортной цепи митохондрий в ткани печени мышей линии BALB/c.

КЛЮЧЕВЫЕ СЛОВА: антифосфолипидный синдром; печень; оксидативныЙ стресс; антиоксидантная система. 


\section{PARAMETERS OF LIVER PROOXIDATIVE-ANTIOXIDANT SYSTEM IN CASES OF EXPERIMENTAL ANTIPHOSPHOLIPID SYNDROME AND L-ARGININ ADMINISTRATION}

\section{Summary}

Introduction. Antiphospholipid syndrome (APS) that is developed due to underlying autoimmune mechanism often causes miscarriage, vessels thrombosis of different localization, cerebrovascular accident, cardiovascular and other diseases that are accompanied by significant activation of free radical processes. Pathogenesis of liver damage in cases of APS has not been adequately studied.

The aim of the study - to establish the changes in parameters of prooxidative-antioxidant system and tissue respiration in liver in cases of experimental antiphospholipid syndrome and L-arginine administration.

Research Methods. Mice of BALB/c line were used in the research. The APS was modeled using cardiolipin emulsified in 75 complete Freund's adjuvant; subsequent injections were administered with incomplete Freund's adjuvant. Cardiolipin was injected intramuscularly four times at a dose of $30 \mu \mathrm{g}$ per 1 injection with 14-day intervals between the injections. For correction, L-arginine hydrochloride $(25 \mathrm{mg} / \mathrm{kg}$ ) was administered once daily during 10 days after APS development.

The activity and content of antioxidant system components (superoxide dismutase, catalase, reduced glutathione) were investigated in liver tissue. The level of lipid peroxidation products was determined by the content of lipid hydroperoxides and TBA-active products. The state of energy-supplying processes of mitochondria was studied due to the activity of succinate dehydrogenase and cytochrome oxidase. The concentration of proteins was determined by Lowry method.

Results and Discussion. In cases of APS in liver the imbalance in functioning of prooxidative antioxidant system (increased activity of superoxide dismutase and catalase, decrease in the content of reduced glutathione, increase in the level of lipids hydroperoxides, TBA-active products), of mitochondrial electron transport chain (decrease in the activity of succinate dehydrogenase, cytochrome oxidase) in cases of experimental antiphospholipid syndrome was evidenced. In cases of experimental APS in presence of L-arginine administration, the re-establishment of activity and content of antioxidant system components, enzymes of mitochondrial electron transport chain, decrease in content of lipid hydroperoxides and TBA-active products in liver was proved.

Conclusion. In cases of experimental antiphospholipid syndrome, L-arginine, in the event of its repeated administration, reduces manifestations of oxidative stress and reactivate enzymes of mitochondrial electron transport chain in liver tissue of $B A L B / c$ mice.

KEY WORDS: antiphospholipid syndrome; liver; oxidative stress; antioxidant system; mitochondrial enzymes.

Отримано 05.07.17

Адреса для листування: О. З. Яремчук, Тернопільський державний медичний університет імені І. Я. Горбачевського, майдан Волі, 1, Тернопіль, 46001, Україна, e-mail: yaremchuk@tdmu.edu.ua. 